\title{
ANALISIS FITUR HAAR MENGGUNAKAN ALGORITMA HAAR-LIKE FEATURE PADA CITRA KENDARAAN BERMOTOR
}

\author{
Nabila Dayu Mega Anjani ${ }^{1)}$, Farida $^{2)}$, Muchamad Kurniawan ${ }^{3)}$ \\ 1), 2), 3) Program Studi Teknik Informatika, Fakultas Teknik Elektro Dan Teknologi Informasi, \\ Institut Teknologi Adhi Tama Surabaya \\ Jl. Arief Rahman Hakim No.100, Surabaya

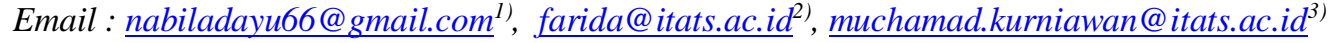

\begin{abstract}
Abstrak
Jenis kendaraan bermotor terdiri dari sepeda motor, mobil, bus dan truk. Setiap jenis kendaraan bermotor memiliki ciri-ciri khusus yang digunakan sebagai pembeda. Pengenalan objek kendaraan berdasarkan jenis dan teknik pengolahan citra telah banyak dikembangkan oleh beberapa peneliti dengan menggabungkan metode deteksi kendaraan salah satunya metode haar like feature. Penelitian ini mencari filter yang tepat untuk digunakan pada proses deteksi kendaraan bermotor. Beberapa proses haar like feature yang dilakukan diantaranya integral image, haar training, haar testing dan labeling. Berdasarkan hasil pengujian pemilihan filter pada proses haar training memperoleh tipe filter (1,2) dapat mengenali 4 objek kendaraan mobil dan 0 objek bis dengan hasil akurasi $80 \%$. Sedangkan tipe filter (2,2) dapat mengenali 1 objek kendaraan mobil dan 0 kendaraan bis dengan hasil akurasi $71 \%$. Pada proses haar testing memperoleh tipe filter $(1,2)$ dapat mengenali 2 kendaraan mobil dan 1 kendaraan bis dengan hasil akurasi 88,8\%. Sedangkan tipe filter (2,2) dapat mengenali 3 objek kendaraan mobil dan 1 objek kendaraan bis dengan hasil akurasi $90 \%$.
\end{abstract}

Kata kunci: Filter, Haar Like Feature, Kendaraan

\begin{abstract}
Types of motorized vehicles consist of motorbikes, cars, buses, trucks. Each type of motorized vehicle has special characteristics that are used as differentiators. The recognition of vehicle objects by type and image processing techniques has been developed by several researchers by combining vehicle detection methods, one of which is the haar like feature method. This research is looking for the right filter to be used in the motor vehicle detection process. Some of the haar like feature processes that are carried out include integral image, haar training, haar testing and labeling. Based on the results of filter selection testing in the haar training process, the filter type $(1,2)$ can recognize 4 car vehicle objects and 0 bus objects with an accuracy of $80 \%$. While the filter type $(2,2)$ can recognize 1 car vehicle and 0 bus vehicle with an accuracy of $71 \%$. In the haar testing process, the filter type $(1,2)$ can recognize 2 cars and 1 bus vehicle with an accuracy of $88.8 \%$. While the filter type (2,2) can recognize 3 car vehicle objects and 1 bus vehicle object with $90 \%$ accuracy results.
\end{abstract}

Keywords : Filter, Haar Like Feature, Vehicle

\section{PENDAHULUAN}

Kamera pemantau (CCTV) lalu lintas yang telah terpasang pada titik kepadatan kendaraan menggunakan program Area Traffic Control System (ATCS). ATCS merupakan sistem pengendali lalu lintas pada persimpangan jalan yang digunakan untuk memperbaiki pengaturan lalu lintas berdasarkan jumlah kendaraan dan waktu tempuh kendaraan.

Pengenalan objek kendaraan berdasarkan jenis dan teknik pengolahan citra telah banyak dikembangkan oleh beberapa peneliti dengan menggabungkan metode deteksi kendaraan. Pengenalan objek dengan memanfaatkan tepi citra dan ektrasi fitur dapat 
dilakukan dengan memperoleh hasil akurasi seberas 92,5\% [1]. Berdasarkan tingginya nilai keakurasian membuat algoritma haar-like feature banyak digunakan untuk mendeteksi obyek. Prosedur klasifikasi gambar menurut [2] berdasarkan nilai fitur.

Terdapat ribuan fitur yang dimiliki algortima haar-like feature. Pemilihan fitur dapat dilakukan berdasarkan objek deteksi atau pemilihan secara acak fitur yang digunakan. Algoritma haar-like feature merupakan fitur yang didasari oleh wavelet haar yaitu sebuah fungsi matematika berbentuk kotak dan memiliki prinsip seperti fungsi fourier [3]

Beberapa peneliti yang telah melakukan penelitian mengenai jenis kendaraan menggunakan beberapa metode yang mempermudah penelitian. Menurut [4] kepadatan kendaraan di jalan raya menggunakan analisa volume traffic. Menurut [5] analisa ini digunakan untuk mengetahui jumlah kendaraan yang bergerak pada suatu arah dan melewati suatu titik atau wilayah per-jam, per-hari, atau mungkin per-minggu. Kepadatan kendaraan di jalan raya berdasarkan hipotesa menggunakan metode adaptif segmentasi untuk menentukan letak dan pengenalan pola. Menggunakan metode Haar Cascade Classifier dan camshaft untuk mengurangi penggunaan resource. Karena metode tersebut sederhana dan tidak menggunakan resorce yang cukup besar. Hasil akurasi pendeteksian kendaraan berdasarkan vidio lalu lintas dalam mendeteksi jenis kendaraan berat memiliki nilai akurasi $42 \%$, mendeteksi jenis kendaraan roda empat memiliki nilai akurasi $90 \%$, mendeteksi jenis kendaraan roda dua memiliki nilai akurasi 81\% [6].

Berdasarkan beberapa penelitian sebelumnya dalam mendeteksi objek pada citra kendaraan menggunakan seluruh fitur yang dimiliki algoritma haar like feature. Penggunaan seluruh fitur yang terdapat pada algoritma haar like feature dapat memudahkan dalam proses pendeteksi, namun membuat proses deteksi berjalan lama dan membuat ruang penyimpanan menjadi besar. Dengan melakukan analisa fitur pada algoritma haar like feature dapat memudah proses deteksi dan memperoleh fitur yang baik atau sesuai digunakan pada citra kendaraan.

Penelitian ini ditujukan untuk menganalisa fitur yang baik atau yang sesuai pada objek kendaraan menggunakan algoritma haar-like feature. Penelitian ini memanfaatan kamera pemantau lalu lintas berupa vidio yang kemudian diproses menjadi gambar tangkapan layar yang akan digunakan sebagai data penelitian. Gambar pantauan lalu lintas akan diolah untuk mengenali jenis kendaraan menggunakan algoritma haar-like feature berdasarkan nilai fitur. Fitur yang diperoleh kemudian akan diuji pada citra lalu lintas untuk mengetahui fitur yang dapat digunakan pada objek kendaraan. Hasil dari penelitian ini dapat mempercepat penelitian selanjutnya tentang pendeteksian kendaraan berdasarkan jenis kendaraan yaitu mobil dan bus.

\section{DASAR TEORI}

\section{a. Pengertian Citra}

Menurut Kamus Besar Bahasa Indonesia citra memiliki makna rupa, gambar, atau gambaran. Namun menurut kamus Webster citra adalah suatu representasi, kemiripan, atau imitasi dari suatu objek atau benda. Citra terbagi menjadi dua yaitu citra diam dan citra bergerak. Citra diam adalah citra tunggal yang tidak bergerak. Sedangkan, citra bergerak adalah rangkaian citra diam yang ditampilkan secara beruntun sehingga memberi kesan pada mata kita sebagai gambar yang bergerak.

\section{b. Haar Like Feature}

Haar-Like Feature adalah metode yang digunakan untuk mendeteksi objek, juga disebut sebagai Viola Jones metode karena pengenalan oleh Paul Viola dan Michael Jones untuk deteksi wajah. 
c. Fitur

Prosedur deteksi objek menurut Viola-Jones mengklasifikasikan gambar berdasarkan nilai fitur sederhana. Ada banyak fitur yang dapat digunakan.
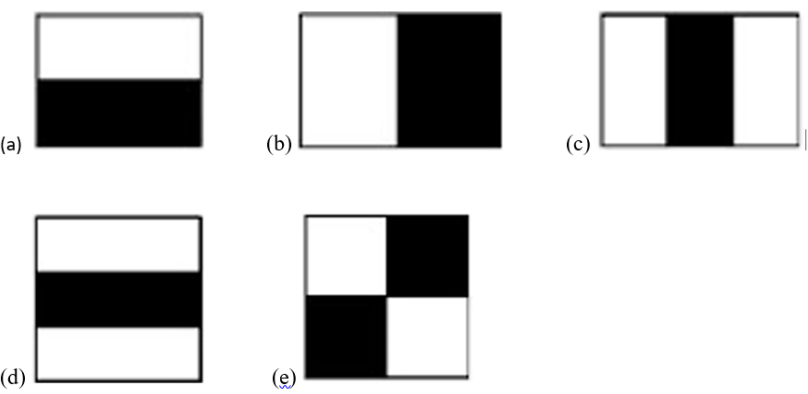

Gambar 1. Fitur Viola\&Jones fitur dua persegi panjang ditunjukkan pada (A) dan (B), gambar (C) dan (D) menunjukkan fitur tiga persegi panjang dan (E) menunjukkan fitur empat persegi panjang. [2]

Nilai dari fitur dua-persegi panjang adalah perbedaan antara jumlah piksel dalam dua wilayah persegi panjang. Gambar 1 adalah daerah yang memiliki ukuran dan bentuk yang sama dan secara horizontal atau vertical berdekatan secara vertical. Fitur tiga persegi panjang menghitung jumlah dalam dua persegi panjang luar dikurangi dari jumlah di persegi panjang pusat. Akhirnya empat persegi panjang Fitur menghitung perbedaan antara pasangan diagonal persegi panjang.

d. Integral Image

Fitur persegi panjang dapat dihitung dengan sangat cepat menggunakan representasi perantara untuk gambar yang kita sebut integral. Gambar integral dilokasi $x, y$ mengandung jumlah piksel di atas dan di sebelah kiri , $y$ :

$$
i i(x, y)=\sum_{x^{\prime} \leq x, y^{\prime} \leq y} i\left(x^{\prime}, y^{\prime}\right),
$$

\section{Keterangan rumus :}

- $\boldsymbol{i} \boldsymbol{i}(\boldsymbol{x}, \boldsymbol{y})$ adalah interal image

- $\boldsymbol{i}\left(\boldsymbol{x}^{\prime}, \boldsymbol{y}^{\prime}\right)$ adalah gambar asli

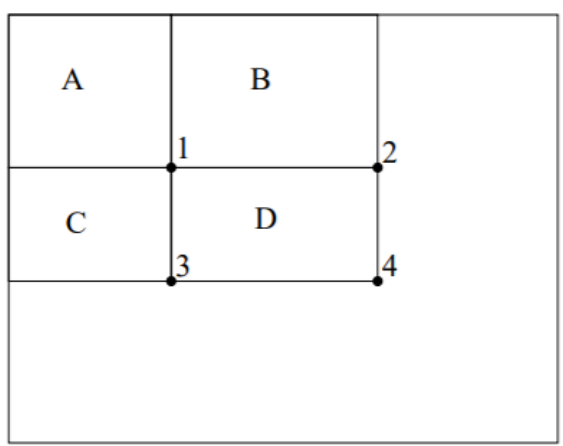

Gambar 2. jumlah piksel dalam persegi panjang dapat dihitung dengan empat referensi array [2]

Nilai gambar integral di lokasi 1 adalah jumlah piksel dalam persegi panjang $A$. Nilai dilokasi 2 adalah $A+B$, dilokasi 3 adalah $A+C$, dan dilokasi 4 adalah $A+B+C+$ $D$. Pada Gambar 2 dapat di ketahui jumlah pada $D$ dapat dihitung sebagai $4+1-(2+$ 3)

Dimana $i i(x, y)$ adalah gambar integral dan $i(x, y)$ adalah gambar asli. Menggunakan pasangan rekurensi berikut : 


$$
\begin{array}{r}
s(x, y)=s(x, y-1)+i(x, y) \\
i i(x, y)=i i(x-1, y)+s(x, y)
\end{array}
$$

Dimana $s(x, y)$ adalah jumlah baris komulatif, $s(x,-1)=0$ dan $i i(-1, y)=0)$ gambar integral dapat dihitung dalam satu melewati gambar asli.

\section{e. Klasifikasi Haar}

Klasifikasi fitur Haar menggunakan integral persegi panjang untuk menghitung nilai suatu fitur. Klasifikasi fitur Haar mengalikan bobot masing-masing persegi panjang dengan luas dan hasilnya ditambahkan bersamaan. Beberapa pengklasifikasi fitur Haar menyusun panggung. Sebuah komparator panggung menjumlahkan semua Haar fitur classifier menghasilkan satu tahap dan membandingkan ini penjumlahan dengan ambang batas panggung. Ambang juga memperoleh konstanta yang diperoleh dari algoritma Ada Boost. Setiap tahap tidak memiliki sejumlah fitur Haar. Sebagai contoh, Kumpulan data Viola dan Jones menggunakan 2 fitur di tahap pertama dan 10 detik. Secara keseluruhan mereka menggunakan total. 38 tahap dan 6060 fitur dengan resolusi gambar 384 x 288 .

\section{f. Akurasi}

Akurasi adalah derajat pendekatan dari pengukuran kuantitas nilai untuk nilai sebenarnya (true). Nilai akurasi diperoleh dari hasil rule yang dihasilkan dari perhitungan decision tree kemudian di uji coba pada data testing dan menghasilkan derajat keakuratan dari rule tersebut setelah di uji coba pada data testing. Tingkat akurasi atau kesalahan adalah salah satu metrik yang paling umum dalam praktik yang digunakan oleh banyak peneliti untuk mengevaluasi kemampuan generalisasi dari pengklasifikasi. Melalui akurasi, classifier terlatih diukur berdasarkan total correctness yang mana merujuk pada total instance yang diprediksi dengan benar oleh classifier terlatih saat diuji dengan data yang tidak terlihat. Misalnya, metrik akurasi digunakan untuk membedakan setiap solusi tunggal dan pilih solusi terbaik yang dihasilkan oleh algoritma klasifikasi tertentu. Hanya yang terbaik solusi yang diyakini model optimal akan diuji dengan data yang tidak terlihat. Berikut rumus perhitungan Accuracy atau akurasi

Keterangan rumus :

$$
\text { Accuracy }=\frac{t p+t n}{t p+f p+t n+f n}
$$

- tp atau true positive adalah jumlah tuple positif yang dilabeli dengan benar oleh classifier. Yang dimaksud tuple positif adalah tuple actual yang berlabel positif, seperti tuple dengan label Bonus=' $Y$ '.

- tn atau true negatives jumlah tuple negatif yang dilabeli dengan benar oleh classifier. Yang dimaksud tuple negatif adalah tuple actual yang berlabel negatuf, seperti tuple dengan label Bonus='Tidak'.

- Fp atau false positive adalah jumlah tuple negatif yang salah dilabeli oleh classifier. Misalnya, sebuah tuple pelanggan yang berlabel Bonus = 'Tidak' tetapi oleh classifier dilabeli Bonus='Ya'.

- Fn atau false negative adalah jumlah tuple positif yang salah dilabeli oleh classifier. Misalnya, sebuah tuple pelanggan yang berlabel Bonus='Ya' tetapi oleh classifier dilabeli Bonus='Tidak'

\section{METODOLOGI PENELITIAN}

a. Rancangan Sistem

Beberapa tahapan yang terdapat pada rancangan sistem yang akan dibuat dapat di lihat pada Gambar 3. 


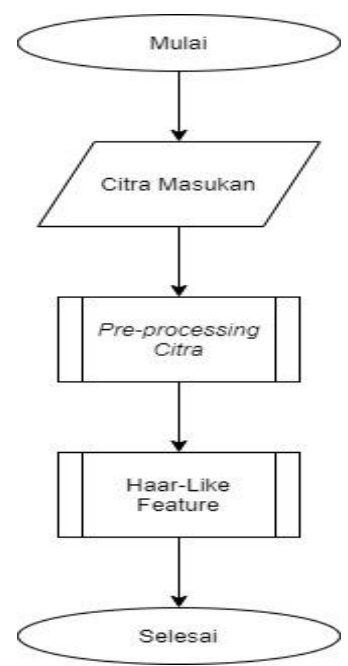

Gambar 3. flowchart alur perancangan sistem

Pada penelitian ini dataset yang digunakan berupa gambar pantauan lalu lintas di Kota Surabaya yang diperoleh dari Dinas Perhubungan Kota Surabaya pada instasi Surabaya Intelligent Transport System (SITS). Berikut beberapa tahapan yang dilakukan :

Citra gambar melalui tahapan preprocessing dimana pada tahap ini citra gambar berwana akan diubah menjadi grayscale, kemudian memperoleh citra biner atau angka yang akan digunakan untuk tahap integral image.

Setelah memperoleh nilai dari integral image selanjutnya tahap haar like feature dimana pada proses ini memiliki beberapa tahapan yang dilakukan diantaranya proses training yaitu mencari filter yang bisa digunakan pada citra kendaraan. kemudian dilanjutkan pada proses testing untuk mengetahui filter yang benar-benar sesuai atau cocok digunakan pada citra kendaraan proses lebih detail dapat diketahui pada sub-bab selanjutnya.

b. Haar Like Feature

Beberapa proses pada Haar-like Feature dapat diketahui pada Gambar 4.

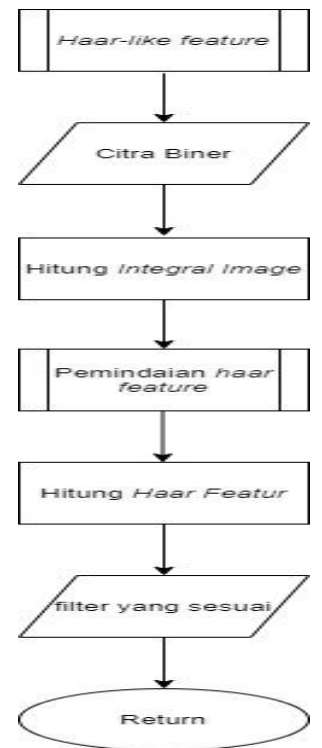

Gambar 4. flowchart haar-like feature

Beberapa tahapan yang dilakukan pada proses haar like feature dapat diketahui dibawah ini: 


\section{Langkah 1. Integral Image :}

Pada tahap ini merupakan proses menghitung citra biner yang diperoleh dari preprocessing. Proses perhitungan dimulai pada bagian kiri atas hingga bagian bagian kanan bawah. Hasil integral image akan digunakan untuk peroses haar like feature.

\section{Langkah 2. Pemindaian Haar Feature :}

Tahap ini merupakan menghitung nilai yang dimiliki pada semua filter haar yang digunakan untuk penelitian ini. Tahap ini memiliki 2 sub tahap yaitu haar training dan haar testing.

\section{Langkah 2a. Haar Training :}

Proses training digunakan untuk melatih filter dalam pengenalan objek kendaraan. proses pertama yang dilakukan membuat sampel positif berisi gambar objek kendaraan mobil dan bis serta sampel negatif berisi objek selain kendaraan seperti latar belakang, pohon, awan dan lain-lain. Hasil yang diperoleh berupa filter yang dapat digunakan pada citra kendaraan. Kemudian filter tersebut akan diuji kembali pada tahap testing.

\section{Langkah 2b. Haar Testing :}

Pada tahap ini akan melakukan uji coba kembali pada filter yang diperoleh dari hasil haar training untuk memperoleh filter yang cocok atau dapat digunakan pada objek kendaraan.

\section{Langkah 3. Labeling :}

Setelah memperoleh filter yang diperoleh dari haar testing. Selanjutnya prose pelabelan atau memberi tanda pada objek kendaraan mobil dan bis yang dapat dikenali oleh sistem.

\section{PENGUJIAN DAN PEMBAHASAN}

a. Implementasi Data

Dataset yang digunakan pada penelitian ini berupa gambar pantauan lalu lintas yang diperoleh dari vidio CCTV lalu lintas Kota Surabaya. Vidio tersebut kemudian diproses menjadi gambar dengan menangkap gambar layar. Ukuran gambar tangkapan layar yang digunakan yaitu 384 x 288 dengan format gambar .jpg. Dataset diperoleh dari pihak Dinas Perhubungan Kota Surabaya devisi lalu lintas. Pengambilan gambar dilakukan pada siang hari sekitar pukul $10.00-12.00$ WIB. Jarak kamera pantauan CCTV yang digunakan $6 \mathrm{~m}^{2}$. pada Gambar 5 beberapa citra yang diperoleh dari kamera pantauan CCTV untuk digunakan sebagai dataset penelitian :

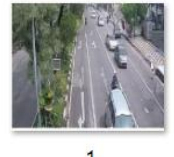

1

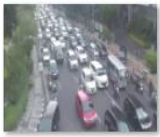

7

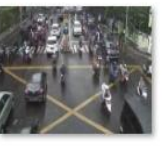

2

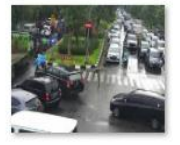

8

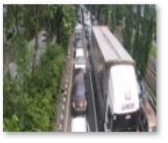

3

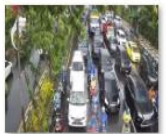

9

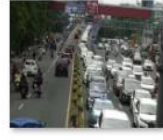

4

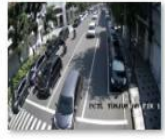

10

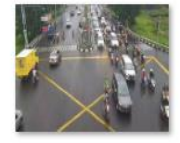

5

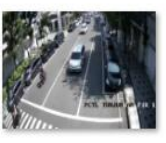

11

Gambar 5. Data citra asli 
Banyak dataset yang digunakan pada penelitian ini 100 gambar tangkapan layar pantauan lalu lintas. Dari banyak dataset yang digunakan kemudian dibagi menjadi 2 yaitu 70 sebagai data training dan 30 sebagai data testing.

b. Implementasi Algoritma

Tahap pertama yang dilakukan yaitu merubah citra warna menjadi citra keabuan atau grayscale. hasil dari proses grayscale dapat diketahui pada gambar 6.
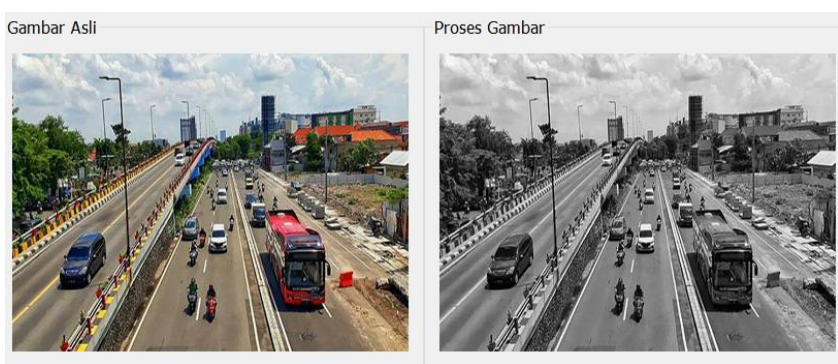

Gambar 6. Hasil grayscale

Tahap selanjutnya yaitu proses intergral image dapat diketahui pada Gambar7. Proses menghitung biner atau angka yang terdapat pada tiap piksel gambar.

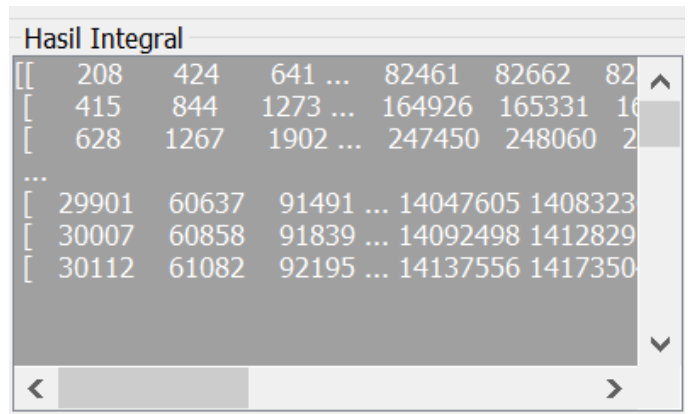

Gambar 7. Hasil Integral Image

Selanjutnya proses haar like feature dilakukan berdasarkan hasil perhitungan integral image pada Gambar 8. Hasil yang ditampilkan pada proses ini yaitu tipe fitur, tinggi fitur, lebar fitur, bagian kiri atas fitur, bagian kanan bawah

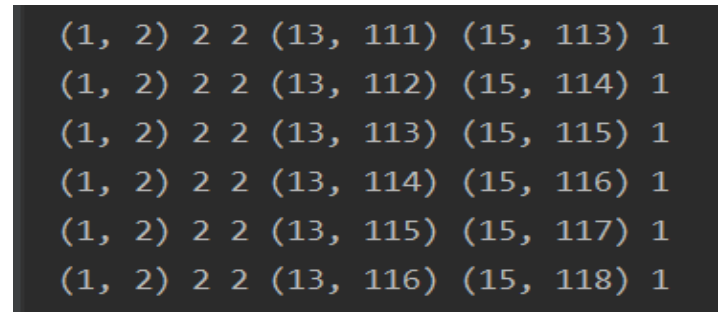

Gambar 8. Hasil haar like feature

Pada proses training tahap pertama yang dilakukan yaitu membuat sampel positif dan negatif. Sampel tersebut digunakan untuk membedakan objek dan yang bukan objek. Selanjutnya dilakukan pemilihan filter yang baik digunakan pada objek kendaraan. Hasil haar training berupa filter seperti Gambar 9 yang nantinya akan diuji kembali ketika proses haar testing untuk memperoleh filter yang bener-benar sesuai dengan citra yang diuji.

$$
\text { Fitur Type Training } \quad:(1,2),(2,1),(3,1),(1,3),(2,2)
$$

\section{Gambar 9. Hasil proses training}

Selanjutnya tahap testing yaitu melakukan uji coba kembali terhadap filter yang didapat pada proses training. Filter yang didapatkan dari proses testing ini kemudian akan 
digunakan untuk proses deteksi yang bisa digunakan untuk penelitian selanjutnya tanpa menggunakan seluruh filter haar.

$\begin{array}{ll}\text { Fitur Type Testing } & :(2,2) \\ \text { Fitur Score } & : 63641\end{array}$

Gambar 10. hasil proses testing

Gambar 10 merupakan hasil proses training berupa filter yang dapat digunakan pada citra kendaraan. Setelah melakukan proses training dan testing untuk memperoleh filter yang baik digunakan untuk pelabelan. Tahap selanjutnya yaitu pelabelan atau penandaan pada objek kendaraan mobil dan bis. Proses pelabelan dapat diketahui pada gambar 4.11. Gambar yang digunakan pada proses pelabelan hasil dari tahapan grayscale atau citra keabuan. Objek yang dikenali diberi tanda kotak berwarna hitam pada gambar.

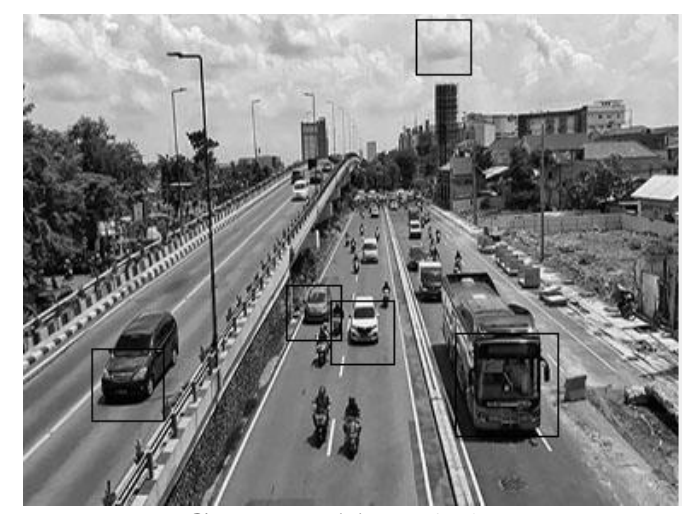

Gambar 11. Labeling

c. Pembahasan

Pada sub bab ini akan ditampilkan hasil uji coba yang telah dilakukan terhadap citra kendaraan untuk mengetahui hasil uji coba program dalam proses haar like feature.

Tabel 1. Hasil akurasi dataset training

\begin{tabular}{|c|c|c|c|c|}
\hline Nama Gambar & Objek Pada Gambar & Objek Yang Dikenali & Filter Yang Diperoleh & Hasil Akurasi \\
\hline $1 . j p g$ & 5 & 2 & $(1,2)$ & $87,5 \%$ \\
\hline $2 . j p g$ & 3 & 1 & $(1,2)$ & $60 \%$ \\
\hline $3 . j p g$ & 3 & 0 & $(1,2)$ & $60 \%$ \\
\hline 4.jpg & 32 & 0 & $(1,2)$ & $96 \%$ \\
\hline 5.jpg & 10 & 0 & $(1,2)$ & $53 \%$ \\
\hline 7.jpg & 13 & 0 & $(1,2)$ & $85 \%$ \\
\hline 7.jpg & 19 & 2 & $(1,2)$ & $100 \%$ \\
\hline 9.jpg & 12 & 0 & $(1,2)$ & $66 \%$ \\
\hline $10 . j p g$ & 13 & 0 & $(1,2)$ & $62,5 \%$ \\
\hline $11 . j p g$ & 13 & 4 & $(1,2)$ & $60 \%$ \\
\hline 12.jpg & 11 & 1 & $(1,2)$ & $42 \%$ \\
\hline 13.jpg & 7 & 0 & $(1,2)$ & $100 \%$ \\
\hline 15.jpg & 12 & 2 & $(1,2)$ & $90 \%$ \\
\hline 16.jpg & 11 & 4 & $(1,2)$ & $90 \%$ \\
\hline 17.jpg & 13 & 0 & $(1,2)$ & $83 \%$ \\
\hline 18.jpg & 13 & 0 & $(3,1)$ & $66 \%$ \\
\hline 19.jpg & 6 & 0 & $(2,2)$ & $75 \%$ \\
\hline 20.jpg & 4 & 2 & $(1,3)$ & $75 \%$ \\
\hline 21.jpg & 9 & 0 & $(2,1)$ & $0 \%$ \\
\hline 22.jpg & 0 & 0 & $(1,2)$ & $25 \%$ \\
\hline
\end{tabular}




\begin{tabular}{|c|c|c|c|c|}
\hline Nama Gambar & Objek Pada Gambar & Objek Yang Dikenali & Filter Yang Diperoleh & Hasil Akurasi \\
\hline 23.jpg & 2 & 0 & $(1,2)$ & $0 \%$ \\
\hline 24.jpg & 10 & 3 & $(1,2)$ & $87,5 \%$ \\
\hline 25.jpg & 11 & 4 & $(1,2)$ & $80 \%$ \\
\hline 26.jpg & 11 & 3 & $(1,2)$ & $77 \%$ \\
\hline 27.jpg & 14 & 3 & $(1,2)$ & $77 \%$ \\
\hline 28.jpg & 12 & 1 & $(1,2)$ & $75 \%$ \\
\hline 29.jpg & 8 & 1 & $(2,2)$ & $71 \%$ \\
\hline 30.jpg & 9 & 2 & $(1,2)$ & $60 \%$ \\
\hline 31.jpg & 4 & 1 & $(1,2)$ & $60 \%$ \\
\hline 32.jpg & 4 & 0 & $(1,2)$ & $66 \%$ \\
\hline 33.jpg & 4 & 0 & $(1,2)$ & $25 \%$ \\
\hline 34.jpg & 2 & 0 & $(1,2)$ & $0 \%$ \\
\hline 35.jpg & 3 & 0 & $(1,2)$ & $0 \%$ \\
\hline 36.jpg & 8 & 1 & $(1,2)$ & $75 \%$ \\
\hline 37.jpg & 8 & 1 & $(1,2)$ & $83 \%$ \\
\hline 38.jpg & 9 & 1 & $(1,2)$ & $85 \%$ \\
\hline 39.jpg & 8 & 1 & $(1,2)$ & $85 \%$ \\
\hline 40.jpg & 9 & 1 & $(1,2)$ & $85 \%$ \\
\hline 41.jpg & 9 & 1 & $(1,2)$ & $85 \%$ \\
\hline 42.jpg & 8 & 0 & $(1,2)$ & $80 \%$ \\
\hline 43.jpg & 3 & 2 & $(1,2)$ & $100 \%$ \\
\hline 44.jpg & 4 & 0 & $(1,2)$ & $75 \%$ \\
\hline 45.jpg & 4 & 1 & $(1,2)$ & $100 \%$ \\
\hline 46.jpg & 2 & 2 & $(1,2)$ & $100 \%$ \\
\hline 47.jpg & 4 & 0 & $\frac{1,2)}{(2,2)}$ & $100 \%$ \\
\hline 48.jpg & 6 & 0 & $(2,2)$ & $100 \%$ \\
\hline 49.jpg & 5 & 1 & $(2,2)$ & $100 \%$ \\
\hline 50.jpg & 6 & 1 & $(2,2)$ & $100 \%$ \\
\hline 51.jpg & 6 & 1 & $(2,2)$ & $100 \%$ \\
\hline 52.jpg & 4 & 1 & $(2,2)$ & $100 \%$ \\
\hline 53.jpg & 6 & 1 & $(2,2)$ & $100 \%$ \\
\hline 54.jpg & 10 & 2 & $(1,2)$ & $87,5 \%$ \\
\hline 55.jpg & 11 & 2 & $(1,2)$ & $88.8 \%$ \\
\hline 56.jpg & 9 & 1 & $(1,2)$ & $80 \%$ \\
\hline 57.jpg & 12 & 1 & $(1,2)$ & $90 \%$ \\
\hline 58.jpg & 6 & 2 & $(3,1)$ & $87,5 \%$ \\
\hline 59.jpg & 8 & 1 & $(2,1)$ & $87,5 \%$ \\
\hline 60.jpg & 9 & 1 & $(1,2)$ & $87,5 \%$ \\
\hline 61.jpg & 3 & 0 & $(2,2)$ & $66 \%$ \\
\hline 62.jpg & 4 & 2 & $(1,3)$ & $100 \%$ \\
\hline 63.jpg & 3 & 0 & $(2,2)$ & $100 \%$ \\
\hline 64.jpg & 4 & 0 & $(1,3)$ & $60 \%$ \\
\hline 65.jpg & 2 & 0 & $(2,2)$ & $50 \%$ \\
\hline 66.jpg & 3 & 1 & $(2,2)$ & $75 \%$ \\
\hline 67.jpg & 0 & 0 & $(2,1)$ & $0 \%$ \\
\hline 68.jpg & 0 & 0 & $(2,1)$ & $0 \%$ \\
\hline 69.jpg & 1 & 0 & $(2,1)$ & $0 \%$ \\
\hline 70.jpg & 2 & 0 & $(1,2)$ & $0 \%$ \\
\hline
\end{tabular}

Dari Tabel 1 diketahui terdapat nilai akurasi yang rendah yaitu 0\%. Penyebab memiliki nilai akurasi $0 \%$ yaitu terdapat objek yang tidak dikenali dengan baik, tidak adanya objek yang dapat dikenali, kesalahan mendeteksi objek. Pelabelan terbanyak terdapat pada nama gambar 14.jpg dengan memperoleh hasil akurasi $100 \%$, serta dapat mengenali objek kendaraan dengan benar sebanyak 4 objek kendaraan mobil.

Rata-rata hasil akurasi yang diperoleh dari haar training sebesar $80 \%$ dengan ratarata tingkat pengenalan objek sebanyak 4 objek kendaraan mobil. Untuk mengetahui hasil akurasi pada proses haar testing dapat diketahui pada tabel berikut.

Tabel 2. Hasil akurasi dataset testing 


\begin{tabular}{|c|c|c|c|c|}
\hline Nama Gambar & Objek Pada Gambar & Objek Yang Dikenali & Filter Yang Diperoleh & Hasil Akurasi \\
\hline 71.jpg & 4 & 2 & $(1,2)$ & $75 \%$ \\
\hline 72.jpg & 4 & 1 & $(1,2)$ & $100 \%$ \\
\hline 73.jpg & 4 & 3 & $(1,2)$ & $100 \%$ \\
\hline 74.jpg & 5 & 3 & $(1,2)$ & $66 \%$ \\
\hline 75.jpg & 7 & 3 & $(1,2)$ & $85 \%$ \\
\hline 76.jpg & 6 & 2 & $(1,2)$ & $83 \%$ \\
\hline 77.jpg & 4 & 1 & $(1,2)$ & $100 \%$ \\
\hline 78.jpg & 4 & 0 & $(1,2)$ & $100 \%$ \\
\hline 79.jpg & 2 & 0 & $(1,2)$ & $66 \%$ \\
\hline 80.jpg & 4 & 2 & $(1,2)$ & $100 \%$ \\
\hline 81.jpg & 3 & 0 & $(1,2)$ & $75 \%$ \\
\hline 82.jpg & 1 & 0 & $(1,2)$ & $100 \%$ \\
\hline 83.jpg & 7 & 5 & $(1,2)$ & $100 \%$ \\
\hline 84.jpg & 5 & 3 & $(1,2)$ & $88.8 \%$ \\
\hline 85.jpg & 4 & 3 & $(2,1)$ & $58,3 \%$ \\
\hline 86.jpg & 6 & 1 & $(2,1)$ & $100 \%$ \\
\hline 87.jpg & 8 & 4 & $(2,2)$ & $90 \%$ \\
\hline 88.jpg & 3 & 0 & $(1,2)$ & $60 \%$ \\
\hline 89.jpg & 7 & 1 & $(3,1)$ & $100 \%$ \\
\hline 90.jpg & 6 & 1 & $(2,1)$ & $60 \%$ \\
\hline 91.jpg & 7 & 2 & $(2,1)$ & $83 \%$ \\
\hline 92.jpg & 8 & 1 & $(3,1)$ & $87,5 \%$ \\
\hline 93.jpg & 2 & 0 & $(3,1)$ & $100 \%$ \\
\hline 94.jpg & 9 & 0 & $(2,2)$ & $0 \%$ \\
\hline 95.jpg & 14 & 1 & $(1,2)$ & $90 \%$ \\
\hline 96.jpg & 11 & 1 & $(1,2)$ & $91 \%$ \\
\hline
\end{tabular}

Tabel 3. Lanjutan hasil akurasi dataset testing

\begin{tabular}{|c|c|c|c|c|}
\hline Nama Gambar & Objek Pada Gambar & Objek Yang Dikenali & Filter Yang Diperoleh & Hasil Akurasi \\
\hline 97.jpg & 10 & 1 & $(1,2)$ & $100 \%$ \\
\hline 98.jpg & 14 & 3 & $(1,2)$ & $91 \%$ \\
\hline 99.jpg & 10 & 1 & $(1,2)$ & $91 \%$ \\
\hline 100.jpg & 12 & 2 & $(1,2)$ & $100 \%$ \\
\hline
\end{tabular}

Dari Tabel 2 terdapat beberapa Nama Gambar yang memperoleh hasil akurasi $100 \%$ karena sistem dapat mengenali objek kendaraan mobil dengan benar. Ada pula yang memperoleh hasil 0\% disebabkan tidak adanya objek kendaraan yang dikenali dengan baik. Rata-rata hasil akurasi haar testing sebesar 90\% dengan rata-rata pengenalan objek sebanyak 3 kendaraan mobil dan 1 kendaraan bis. Dari hasil akurasi yang diperoleh dapat disimpulkan filter yang dapat digunakan untuk proses deteksi kendaraan mobil dan bis yang akan dilakukan peneliti selanjutnya yaitu filter tipe $(1,2)$ dan $(2,1)$.

\section{KESIMPULAN}

a. Kesimpulan

Setelah melakukan pengujian pada sistem menggunakan metode haar like feature untuk menentukan filter yang sesuai pada citra kendaraan mobil dan bis menggunakan citra gambar pantauan lalu lintas di Surabaya. Maka dapat disimpulkan sebagai berikut : Nilai akurasi terbesar yaitu 100\% dengan hasil pelabelan sebanyak 1 pada objek kendaraan mobil. Sedangkan pada pelabelan terbanyak 4 objek terdiri dari 3 kendaraan mobil dan 1 kendaraan bis memperoleh hasil akurasi sebesar 90\%. Nilai akurasi terendah sebesar $0 \%$ karena tidak adanya objek yang dikenali pada saat proses pelabelan. Dari hasil akurasi tersebut memiliki 2 filter yang sesuai digunakan pada citra kendaraan mobil dan bis yaitu filter tipe $(1,2)$ dan $(2,1)$ atau sering disebut edge features.

b. Saran 
Dari hasil penelitian yang telah dilakukan ada beberapa saran untuk pengembangan penelitian selanjutnya. Berikut saran yang tersebut.

1. Resolusi vidio yang digunakan ditingkatkan menjadi 1280 x 720 serta gambar tangkapan layar yang diperoleh ditingkatkan menjadi 852 x 480 untuk memperoleh hasil filter yang baik serta memudahkan pengenalan objek kendaraan

2. Dataset yang digunakan untuk penelitian selanjutnya memliki kualitas gambar yang bagus dan jelas untuk memudahkan proses pelabelan.

3. Resolusi gambar sampel positif dan sampel negatif dibuat satu ukuran yang sama untuk memudahkan pengenalan objek

4. Nilai perbandingan yang digunakan untuk proses training dan testing dilakukan secara otomatis berdasarkan hasil objek yang diteliti dan nilai haar like feature

5. Filter yang digunakan pada proses pemindaian filter dapat ditambahkan untuk memperoleh hasil filter yang lebih baik lagi

6. Melakukan pengujian kembali pada setiap filter untuk memperoleh hasil pelabelan sesuai dengan objek penelitian dan memperoleh hasil akurasi yang baik

\section{Daftar Pustaka}

[1] Farida and Rani Rotul Muhima, "Geometric Invariant Moment Pada Aplikasi Image Retrieval Pendeteksian Batik Parang Rusak/Barong Yogyakarta," Semin. Nas. Sains dan Teknol. Terap. VI 2018, pp. 521-526, 2018.

[2] P. Viola and M. Jones, "Rapid object detection using a boosted cascade of simple features," Proc. IEEE Comput. Soc. Conf. Comput. Vis. Pattern Recognit., vol. 1, no. July 2014, 2001.

[3] P. Purwanto, B. Dirgantoro, and A. N. Jati, "Implementasi Face Identification Dan Face Recognition Pada Kamera Pengawas Sebagai Pendeteksi Bahaya," eProceedings Eng., vol. 2, no. 1, pp. 718-724, 2015.

[4] G. Wang, D. Xiao, and J. Gu, "Review on Vehicle Detection Based on Video for Traffic Surveillance," no. October, 2008.

[5] T. Elektro and U. Katolik, "Perancangan Pengaturan Sistem Traffic Light Dengan Cctv Dinamis: Deteksi Kepadatan Jalan Dengan Citra Digital Maket Jalan Simpang Empat."

[6] A. M. Handayani, "Intisari Abstract Vehicle Counting System On A Highway Using," 2015. 